\title{
Carbamoylation of primary, secondary and aromatic amines by dimethyl carbonate in a flow system over solid catalysts
}

\author{
Magdalena Litwinowicz ${ }^{1 *}$ and Jacek Kijeński
}

\begin{abstract}
Background: Carbamate esters represent an important class of organic compounds which find wide application in chemical industry. Classical procedures for the preparation of carbamates are based on the reaction with a very risky compound - phosgene or phosgene derivatives.

Results: A phosgene-free flow-system synthesis of eight carbamates in the reaction of various amines with dimethyl carbonate has been presented. The influence of amine order and structure on their activity in the carbamoylation process was studied. $\mathrm{Fe}_{2} \mathrm{O}_{3}, \mathrm{Fe}_{2} \mathrm{O}_{3} / \mathrm{SiO}_{2}, \mathrm{Fe}_{2} \mathrm{O}_{3} / \mathrm{CoO} / \mathrm{NiO} / \mathrm{SiO}_{2}, \mathrm{TZC}-3 / 1$ and $\mathrm{T}-4419$ were used as catalysts for the process.

Conclusions: The iron - chrome catalyst TZC-3/1 was found to be the most active leading to approx. $70 \%$ yield of methyl $\mathrm{N}$-hexylcarbamate with an $80 \%$ selectivity in the reaction of $\mathrm{n}$-hexylamine with dimethyl carbonate at $150^{\circ} \mathrm{C}$.
\end{abstract}

Keywords: Carbamate ester, Amine, Flow system, Dimethyl carbonate

\section{Background}

In the drive for sustainability and efficiency in chemical processes, an increasing number of environmentally friendly processes are being developed to reduce the application of hazardous materials and minimize energy consumption. The phosgene-free synthesis of carbamates from amines can be regarded as a step in this direction.

The reaction of amines with organic carbonates such as dimethyl carbonate proceeds as follows:

$$
\mathrm{RNH}_{2}+\mathrm{R}^{\prime} \mathrm{OC}(\mathrm{O}) \mathrm{OR}^{\prime} \stackrel{\text { (cat.) }}{\rightarrow} \mathrm{RNHC}(\mathrm{O}) \mathrm{OR}^{\prime}+\mathrm{R}^{\prime} \mathrm{OH}
$$

$\mathrm{R}^{\prime}=$ alkyl, aryl

This is an environmentally benign synthetic route to carbamate esters - compounds having wide range of applications in the chemical industry. They are important intermediates in the synthesis of pharmaceuticals, agrochemicals and can also be used as protecting groups for amine functionality [1-3].

\footnotetext{
* Correspondence: magdalena.litwinowicz@ichp.pl

1 Department of Organic Technology and Separation Processes in Industrial

Chemistry Research Institute, Rydygiera 8, 01-793 Warsaw, Poland

Full list of author information is available at the end of the article
}

From the environmental point of view, other synthetic methods for the synthesis of carbamates have many disadvantages [4-7] as shown in Figure 1.

Toxic and corrosive phosgene is required for reactions 1 and 2 (Figure 1). The isocyanate is produced by the reaction of alkylamine with phosgene. A larger than stoichiometric amount of bases such as $\mathrm{NaOH}$ is required to neutralize the $\mathrm{HCl}$ produced in reactions 2 and 3 while reactions 4-6 must be performed at high temperatures and pressures.

The carbamoylation reaction [Eq.(1)] has recently attracted considerable attention because it provides a non-phosgene route to $\mathrm{N}$-alkyl carbamate [8]. Dimethyl carbonate (DMC) is a safe, clean and green carbamoylating agent with lower negative environmental impact [9-11]. However, the described reaction requires a suitable catalyst to promote the specific process at acceptable conversion rate and with satisfactory selectivity to carbamates. Many catalytic systems have been developed for carbamoylation of amines with DMC. These include enzymes [12], ionic liquids [13,14], organic bases [15] and metal derivatives [16-22].

In this work, a continuous flow phosgene-free synthesis of eight carbamates in the reaction of various amines 


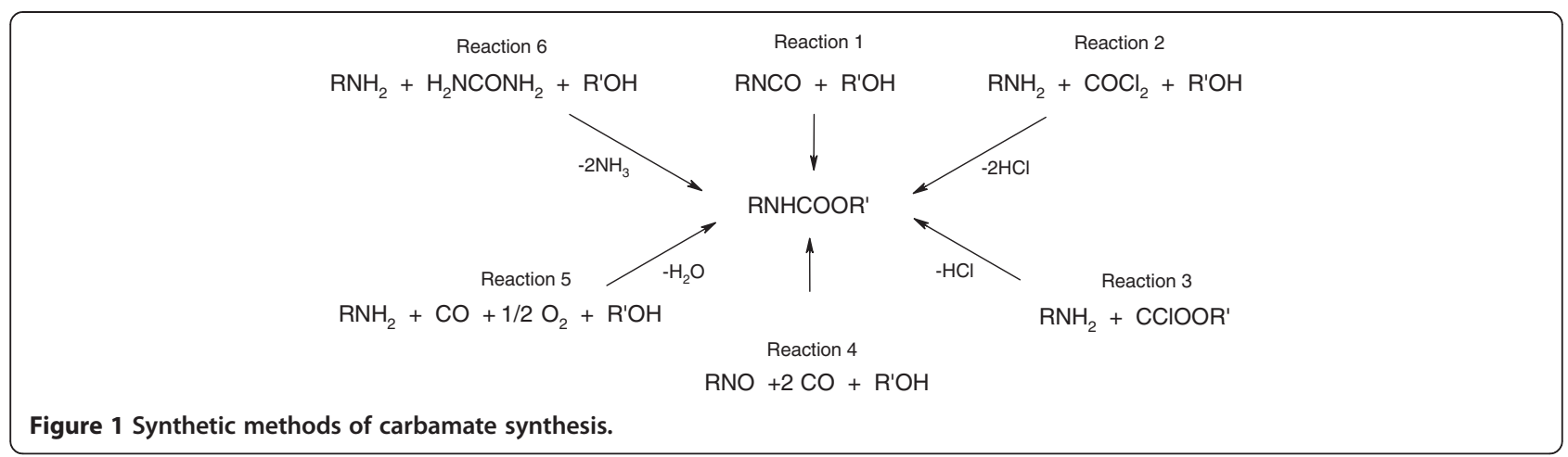

with dimethyl carbonate has been performed. The influence of the order and structure of the amines on their reactivity in carbamoylation process was studied and the activity of five heterogeneous catalysts investigated.

\section{Experimental Materials}

Hexylamine HA, n-butylamine BA, cyclohexylamine CHA, sec-butylamine secBA, dipropylamine diPrA, dibutylamine diBA, benzylamine benzA and aniline were obtained from Merck while DMC was obtained from Aldrich. The reactants were used without any further purification - purity > $99 \%$ as determined by gas chromatography.

\section{Catalyst preparation and composition}

98\% $\mathrm{Fe}_{2} \mathrm{O}_{3}$ was obtained by temperature programmed decomposition of iron (III) nitrate nonahydrate from Sigma Aldrich. 10 wt $\% \mathrm{Fe}_{2} \mathrm{O}_{3} / \mathrm{SiO}_{2}$ and $\mathrm{Fe}_{2} \mathrm{O}_{3} / \mathrm{CoO} /$ $\mathrm{NiO} / \mathrm{SiO}_{2}\left(10 \mathrm{wt} \% \mathrm{Fe}_{2} \mathrm{O}_{3}, 10 \mathrm{wt} \% \mathrm{CoO}\right.$ and $10 \mathrm{wt} \%$ $\mathrm{NiO})$ catalysts were prepared by incipient wetness impregnation of $\mathrm{SiO}_{2}$ (Evonik - AEROSIL 200) with a solution of the appropriate salt. TZC-3/1 catalyst was obtained as a commercial product from Grupa Azoty Tarnów (71.5 wt\% $\mathrm{Fe}_{2} \mathrm{O}_{3}, 7.3$ wt\% $\mathrm{Cr}_{2} \mathrm{O}_{3}, 1.25$ wt $\% \mathrm{CuO}$, 0.1 wt\% $\mathrm{Na}$ and 0.015 wt\% S). T-4419 (21 wt\% $\mathrm{Cr}_{2} \mathrm{O}_{3}$, $78.95 \mathrm{wt} \% \mathrm{CuO}$ ) was a commercial product from Süd Chemie.

All catalysts were dried at $393 \mathrm{~K}$ for $12 \mathrm{~h}$ and then calcined at $773 \mathrm{~K}$ for $4 \mathrm{~h}$ before reactions.

\section{Specific surface area}

The specific surface area using the Brunner Emmett Teller method $\left(\mathrm{S}_{\mathrm{BET}}\right)$ and pore volume [Barrett-JoynerHalenda (BJH) method] of the catalysts are presented in Table 1.

\section{Reaction procedure for carbamate synthesis}

Reactions were performed in a flow system (continuous high-pressure flow reactor) with a fixed bed of $2 \mathrm{~g}$ of catalyst at a temperature range of $50^{\circ} \mathrm{C}$ to $150^{\circ} \mathrm{C}$. Inert glass beads ( $2 \mathrm{~g}$ ) were placed on the catalyst bed for reactions without catalyst (Figure 2). A mixture of the selected amine and DMC (molar ratio DMC : amine $=2: 1$ ) was introduced into the reactor at a flow rate of $24 \mathrm{ml} / \mathrm{h}$ and pressure 9.0 $\mathrm{MPa}$. The flow system experiments were performed with weight hourly space velocity $4 \mathrm{~g}$ amine $/ 1 \mathrm{~g}$ catalyst (glass beads) $\cdot \mathrm{h}$.

The first product sample for analysis was taken after $60 \mathrm{~min}$ of reaction time (period needed to reach reaction steady-state). After the initial sample was taken the reaction temperature was raised every $30 / 40^{\circ} \mathrm{C}$ to the final value of $150^{\circ} \mathrm{C}$. Samples were taken only after reaction stability was observed.

Two reactions were performed in a batch reactor for comparison purposes according to the art in literature [23]. In the first reaction, a mixture of DMC/amine (molar ratio 5:1) was placed in the reactor at $15.0 \mathrm{MPa}$ at room temperature for 24 hours. The second reaction was performed with DMC/amine molar ratio of 2:1 at a pressure of $9.0 \mathrm{MPa}$ at $150^{\circ} \mathrm{C}$ for 24 hours.

\section{Reaction products and analysis}

The composition of the reaction products was determined using a Hewlett-Packard GC/MS chromatograph (HP 5890 II PLUS GC/5989 MS Engine) equipped with a FID detector and a Carbowax capillary column $(30 \mathrm{~m} \times$ $0.25 \mathrm{~mm}$ i.d., $0.25 \mu \mathrm{m}$ film thickness). Amine conversion values were determined as a difference in the concentrations of the inlet and outlet streams. Selectivity was calculated as the ratio of the number of moles of

Table 1 Specific surface areas of the catalyst systems

\begin{tabular}{llll}
\hline Catalyst & $\begin{array}{l}\text { Specific surface } \\
\text { area }\left(\mathbf{S}_{\text {BET }}\right) \\
{\left[\mathbf{m}^{2} / \mathbf{g}\right]}\end{array}$ & $\begin{array}{l}\text { Pore volume } \\
{\left[\mathbf{c m}^{3} / \mathbf{g}\right]} \\
(\mathbf{B J H} \text { adsorption) }\end{array}$ & $\begin{array}{l}\text { Average } \\
\text { particle } \\
\text { size }[\mathbf{n m}]\end{array}$ \\
\hline $98 \% \mathrm{Fe}_{2} \mathrm{O}_{3}$ & 131 & 0.20 & 46 \\
$\mathrm{Fe}_{2} \mathrm{O}_{3} / \mathrm{CoO} / \mathrm{NiO} / \mathrm{SiO}_{2}$ & 8 & 0.05 & 725 \\
$\mathrm{~T}-4419$ & 28 & 0.11 & 214 \\
$\mathrm{TZC}-3 / 1$ & 135 & 0.20 & 44 \\
\hline
\end{tabular}




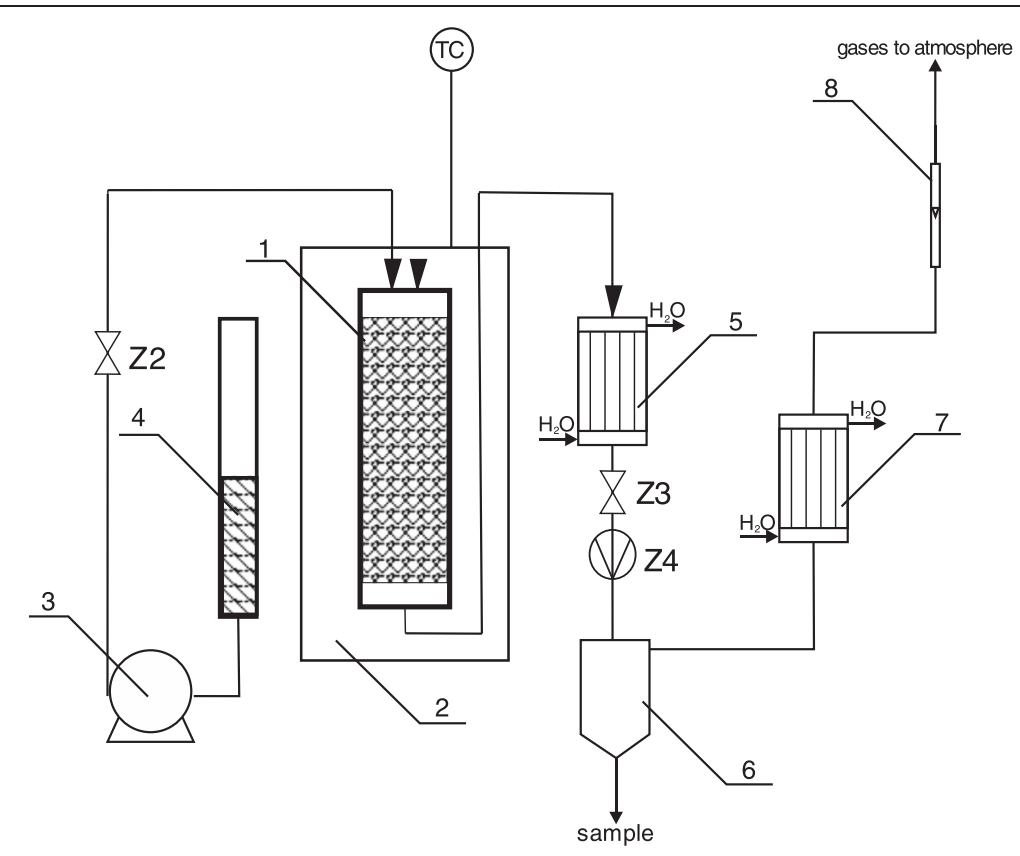

Figure 2 Reaction set-up 1 - reactor, 2 - thermostat, 3 - pomp, 4 - dispenser, 5 - water condenser, 6 - separator, 7 - reflux condenser, 8 - rotameter.

amine to number of moles of all products formed in the reaction.

The number of replicates was 3 for all experiments and the measurement errors did not exceed $5 \%$ of measured value.

Carbamate esters were the main products obtained in the reactions. Due to the fact that dimethyl carbonate can react either as carbamoylating or methylating agent, some side products, especially $\mathrm{N}$-methylated amines, were obtained in the reactions.

Figure 3 illustrates possible reaction routes [24].

\section{Results and discussion}

Non catalytic reactions

Thermal carbamoylation of $H A$ - the influence of reaction temperature

In order to determine the influence of reaction temperature on the conversion of $\mathrm{HA}$ as well as the yield of methyl N-hexylcarbamate the reaction of HA with DMC at various temperatures was performed. The product yield, HA conversion and selectivity towards carbamate are presented in Figure 4. An increase in the yield of the main product was observed as the reaction temperature was raised subsequently from 50 to $150^{\circ} \mathrm{C}$. Though the highest yield (over $50 \%$ ) was achieved at $150^{\circ} \mathrm{C}$, selectivity towards carbamate decreased slightly from almost $84 \%$ at $80^{\circ} \mathrm{C}$ to $78 \%$. This was most probably caused by the initiation of side-reactions to the undesired product$\mathrm{N}$-methylhexylamine. An increase in $\mathrm{HA}$ conversion from $10.4 \%$ to $67.2 \%$ was observed with increasing reaction temperature.

\section{The carbamoylation reaction of HA under different reaction pressures}

The effect of the pressure of the reactant mixture on the yield of methyl $\mathrm{N}$-hexylcarbamate, the conversion

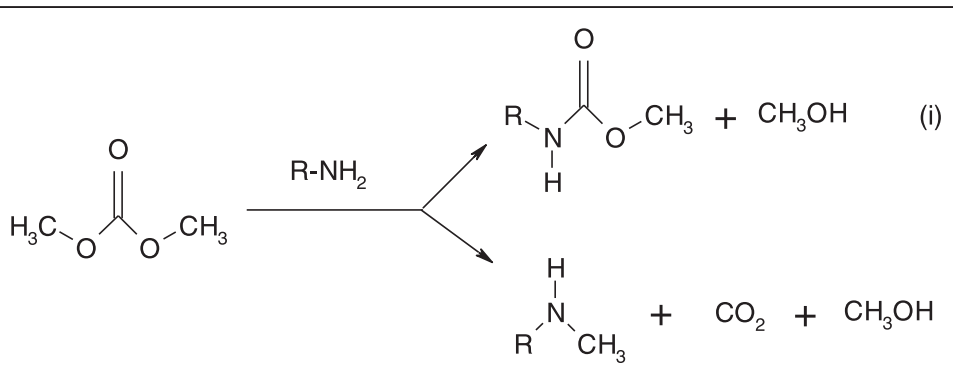

Figure 3 Dual behavior of DMC. (i) Carbamoylation. (ii) Methylation. 


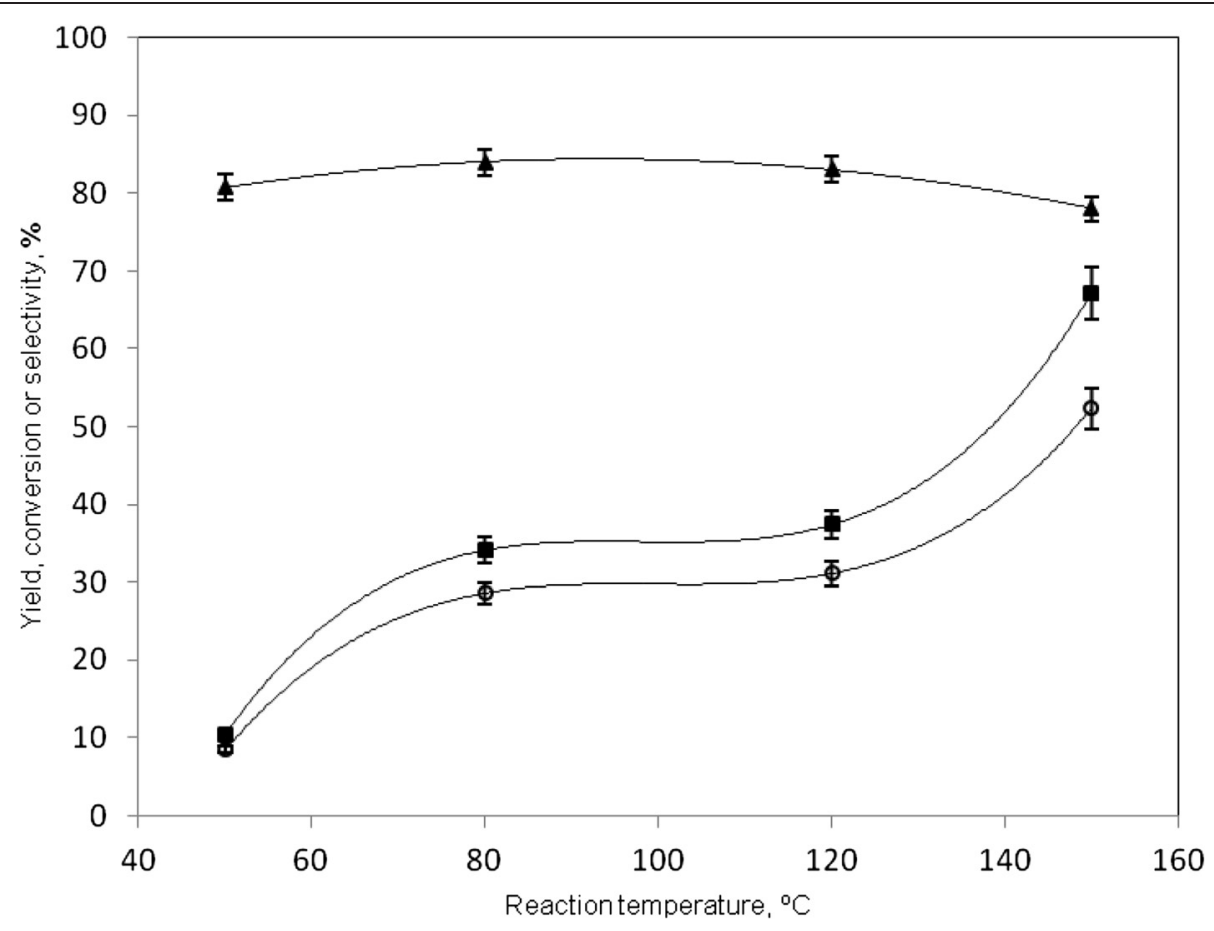

Figure 4 Effect of reaction temperature on the conversion of $\mathrm{HA}$, yield of methyl $\mathrm{N}$-hexylcarbamate and selectivity towards 1 . Reaction conditions: reactant mixture pressure $=9.0 \mathrm{MPa}$, molar ratio $\mathrm{DMC} / \mathrm{HA}=2: 1$, reactant mixture flow $=24 \mathrm{ml} / \mathrm{h}$. (o) yield of $\mathbf{1}$, ( $\mathbf{(})$ conversion of $\mathrm{HA}$, ( $\mathbf{\Delta})$ selectivity towards $\mathbf{1}$. The number of replicates was 3.

of HA and selectivity towards carbamate is presented in Figure 5.

The advantage of applying higher pressure on the reaction process can be observed. HA conversion increased from $51.4 \%$ to $67.2 \%$ with an increase in the pressure from 0.1 $\mathrm{MPa}$ to $9.0 \mathrm{MPa}$. The highest yield of methyl N-hexylcarbamate was obtained under 9.0 $\mathrm{MPa}$ (from $26.1 \%$ to $52.4 \%$ ) and selectivity towards methyl $\mathrm{N}$-hexylcarbamate increased from $50.8 \%$ to $78 \%$ at $5.0 \mathrm{MPa}$ and 9.0 MPa respectively.

The carbamoylation reactions of aliphatic amines with DMC under high pressure in the absence of any catalyst has recently been explored by Margetić and co-workers [23]. High yields (60-100\%) of carbamates were obtained due to the very high pressure $(800 \mathrm{MPa})$ and long reaction times (16-24 h) applied in the described experiments. For example, reaction of benzylamine and DMC performed at room temperature for 16 hours resulted in a total conversion of benzylamine to methyl N-benzylcarbamate.

The reaction of $\mathrm{n}$-hexylamine with DMC under similar conditions (room temperature, 15.0 MPa, 24 h) was therefore performed, but only $5 \%$ of methyl $\mathrm{N}$-hexylcarbamate was obtained. The same reaction performed at $150^{\circ} \mathrm{C}$ under a pressure of $9.0 \mathrm{MPa}$ for 24 hours. A $90 \%$ conversion of $\mathrm{HA}$ and $77 \%$ methyl $\mathrm{N}$-hexylcarbamate yield was obtained.
The carbamoylation reactions of various amines with DMC Eight aliphatic amines HA, BA, CHA, secBA, benzA, diBA, diPA and aniline were studied to investigate the influence of amine order and structure on their reactivity in the synthesis of carbamates.

The results of the reactions of linear or branched aliphatic primary amines $\mathrm{RNH}_{2}$ with DMC at reaction

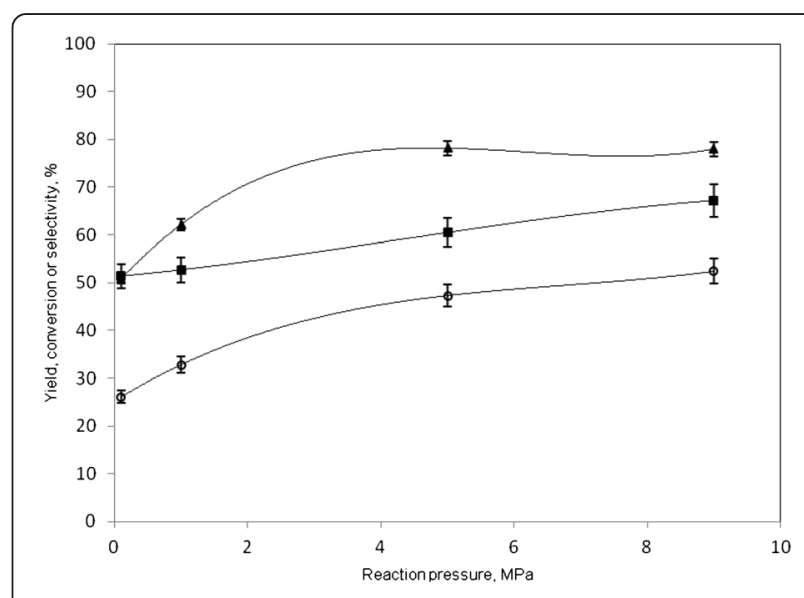

Figure $\mathbf{5}$ Effect of reactant mixture pressure on the conversion of HA, yield of 1 and selectivity towards 1 . Reaction conditions: reaction temperature $=150^{\circ} \mathrm{C}$, molar ratio $\mathrm{DMC} / \mathrm{HA}=2: 1$, reactant mixture flow $=24 \mathrm{ml} / \mathrm{h}$. (o) yield of $\mathbf{1},(\mathbf{v})$ conversion of $\mathrm{HA},(\mathbf{\Delta})$ selectivity towards $\mathbf{1}$. The number of replicates was 3 . 
temperature of $150^{\circ} \mathrm{C}$ in the absence of a catalyst are presented in Table 2. Linear amines HA and BA underwent a higher conversion in the carbamoylation process than non-linear CHA, 2BA and BenzA.

The highest yield of carbamate was obtained in reaction with $\mathrm{HA}$ - over $50 \%$ and a high selectivity towards methyl N-hexylcarbamate - almost $80 \%$. Low selectivities towards expected carbamates and low yields of carbamates in the case of nonlinear or cyclic amines indicate that the methylation reaction took place.

In the case of secondary aliphatic amines $\mathrm{R}_{1} \mathrm{R}_{2} \mathrm{NH}_{2}$ only trace amounts of methyl $\mathrm{N}$-dibutylcarbamate and methyl $\mathrm{N}$-dipropylcarbamate were obtained in reactions with DMC. Very low selectivity was observed under the investigated reaction conditions $\left(150^{\circ} \mathrm{C}, 9.0 \mathrm{MPa}\right)$. These are much less reactive than primary amines.

Aniline was selected as the simplest model of aromatic amines. In contrast to aliphatic amines, $\mathrm{N}$-methylation is the preferred route in reactions between aniline and DMC (Figure 6). The only product observed in our experiments without catalysts was $\mathrm{N}$-methylaniline $(3.5 \%$ at $150^{\circ} \mathrm{C}$ ). Aniline did not react with dimethyl carbonate towards methyl N-phenylcarbamate without a catalyst. This is in accordance with the studies and results presented by other research groups [23,25-27]. Margetic and co-workers found that aromatic amines such as aniline did not react with dimethyl carbonate at room temperature (800 MPa) for 24 hours [23]. Yoshida and co-workers also investigated the methoxycarbonylation of diamines with methyl phenyl carbonate (MPC) under a nitrogen atmosphere at $160^{\circ} \mathrm{C}$ for 5 hours. Aniline did not react with MPC under such conditions. Methoxycarbonylation did not proceed in the absence of catalyst even at a reaction temperature of $180^{\circ} \mathrm{C}$ [25]. Zhang and co-workers have investigated the reaction of aniline with DMC catalyzed by acid-base bifunctional ionic liquids at $160^{\circ} \mathrm{C}$ for 4 hours and obtained methyl N-phenyl carbamate with a yield of $8 \%$ and methyl N-methyl-Nphenyl carbamate with a yield of $72 \%$. The activity of the

Table 2 Carbamoylation of primary aliphatic amines $\mathbf{R N H}_{2}$ with DMC

\begin{tabular}{llll}
\hline Amine & $\begin{array}{l}\text { Yield of } \\
\text { carbamate* [\%] }^{*}\end{array}$ & $\begin{array}{l}\text { Conversion } \\
\text { of amine [\%] }\end{array}$ & $\begin{array}{l}\text { Selectivity towards } \\
\text { carbamate [\%] }\end{array}$ \\
\hline n-Hexyl & 52.4 & 67.2 & 78.0 \\
n-Butyl & 32.6 & 51.1 & 63.8 \\
Cyclohexyl & 1.3 & 5.2 & 25.0 \\
Sec-Butyl & 1.4 & 10.3 & 13.5 \\
Benzyl & 13.6 & 25.6 & 53.1
\end{tabular}

*GC-yield versus amine.

Molar ratio of amine: DMC $=2: 1$, WHSV $=4 \mathrm{~g}$ amine $/ 1 \mathrm{~g}$ catalyst $\cdot \mathrm{h}$, reactant mixture pressure $=9.0 \mathrm{MPa}$, reaction temperature $=150^{\circ} \mathrm{C}$. The number of replicates was 3 .

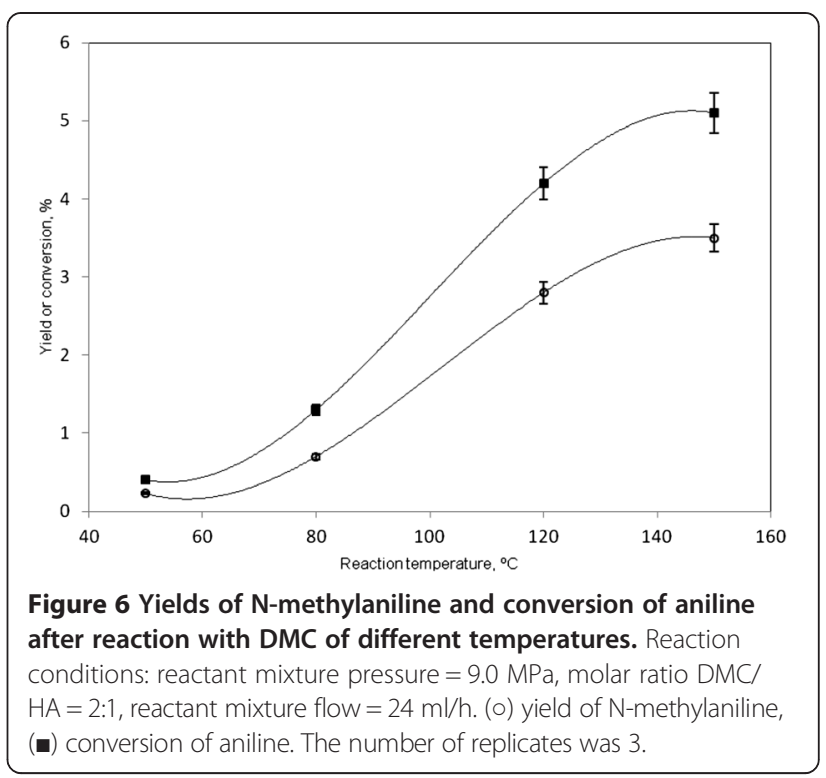

bifunctional catalyst is credited to the ability to activate aniline and DMC cooperatively with its acidic and basic sites [26]. Dhakshinamoorthy and co-workers did not obtain methyl $\mathrm{N}$-phenylcarbamate in the reaction of aniline with $\mathrm{DMC}\left(170^{\circ} \mathrm{C}, 8 \mathrm{~h}\right)$ over $\mathrm{Al}_{2}(\mathrm{BDC})_{3}$ [27]. Our studies confirmed the earlier results.

\section{Catalytic reactions}

After investigating the influence of amine order and structure in reactions without a catalyst, $n$-hexylamine HA was chosen as a representative of aliphatic primary amine for carbamoylation reactions with DMC in the presence of a series of catalysts. The results are presented in Table 3. Three of tested catalysts were found to be active in carbamoylation of HA. The highest amine conversion was found to take place in the presence of the iron - chrome catalyst TZC-3/1. An almost $70 \%$ yield of methyl N-hexylcarbamate was achieved, and a very high selectivity - over $80 \%$ as compared to non-catalytic reaction.

Experiments were performed with a secondary amine diBA using $98 \% \mathrm{Fe}_{2} \mathrm{O}_{3}, \mathrm{Fe} / \mathrm{CoO} / \mathrm{NiO} / \mathrm{SiO}_{2}$ and TZC-3/1 as catalysts. The three catalysts were active in the reaction of diBA with DMC, though very small quantities of methyl N-dibutylcarbamate were obtained. The observed low selectivities towards methyl $\mathrm{N}$-dibutylcarbamate indicate a preference to the alkylation route (Table 4).

TZC 3/1 was the only catalyst applied for aniline transformations. Only trace amounts of methyl N-phenylcarbamate were obtained while the yield of $\mathrm{N}$-methylaniline increased from $3.5 \%$ to $10 \%$. A high selectivity towards formation of N-methylaniline - almost $70 \%$, suggest that 
Table 3 Carbamoylation of $n$-hexylamine with DMC in the presence of different catalysts

\begin{tabular}{|c|c|c|c|c|}
\hline Catalyst & $\begin{array}{l}\text { Temperature } \\
{\left[{ }^{\circ} \mathrm{C}\right]}\end{array}$ & $\begin{array}{l}\text { Yield of } \\
\text { carbamate* } \\
\text { [\%] }\end{array}$ & $\begin{array}{l}\text { Conversion } \\
\text { of amine } \\
\text { [\%] }\end{array}$ & $\begin{array}{l}\text { Selectivity } \\
\text { towards } \\
\text { carbamate } \\
{[\%]}\end{array}$ \\
\hline \multirow{4}{*}{-} & 50 & 8.4 & 10.4 & 80.8 \\
\hline & 80 & 28.6 & 34.1 & 83.9 \\
\hline & 120 & 31.1 & 37.4 & 83.2 \\
\hline & 150 & 52.4 & 67.2 & 78.0 \\
\hline \multirow{4}{*}{$98 \% \mathrm{Fe}_{2} \mathrm{O}_{3}$} & 50 & 7.9 & 9.8 & 81.0 \\
\hline & 80 & 31.3 & 38.3 & 81.7 \\
\hline & 120 & 42.8 & 49.5 & 86.5 \\
\hline & 150 & 63.5 & 77.0 & 82.5 \\
\hline \multirow{4}{*}{$\mathrm{Fe}_{2} \mathrm{O}_{3} / \mathrm{SiO}_{2}$} & 50 & 5.2 & 10.8 & 48.0 \\
\hline & 80 & 26.1 & 34.6 & 75.5 \\
\hline & 120 & 32.8 & 45.5 & 72.1 \\
\hline & 150 & 51.3 & 72.1 & 71.2 \\
\hline \multirow{4}{*}{ T-4419 } & 50 & 5.5 & 7.1 & 77.7 \\
\hline & 80 & 17.0 & 22.8 & 74.5 \\
\hline & 120 & 28.3 & 39.3 & 72.1 \\
\hline & 150 & 41.0 & 65.1 & 63.0 \\
\hline \multirow{4}{*}{$\begin{array}{l}\mathrm{Fe}_{2} \mathrm{O}_{3} / \mathrm{CoO} / \\
\mathrm{NiO} / \mathrm{SiO}_{2}\end{array}$} & 50 & 5.5 & 6.9 & 79.6 \\
\hline & 80 & 27.7 & 34.2 & 81.1 \\
\hline & 120 & 35.9 & 43.9 & 81.7 \\
\hline & 150 & 59.4 & 73.2 & 81.2 \\
\hline \multirow{4}{*}{ TZC-3/1 } & 50 & 9.2 & 11.3 & 81.1 \\
\hline & 80 & 34.8 & 42.5 & 81.9 \\
\hline & 120 & 51.8 & 61.4 & 84.3 \\
\hline & 150 & 68.3 & 83.1 & 82.2 \\
\hline
\end{tabular}

*GC-yield versus amine.

Molar ratio of amine: DMC $=2: 1$, WHSV $=4 \mathrm{~g}$ amine $/ 1 \mathrm{~g}$ catalyst $\cdot h$, reactant mixture pressure $=9.0 \mathrm{MPa}$.

The number of replicates was 3.

this catalyst promoted the methylation reaction process rather than carbamoylation.

\section{Conclusions}

The carbamoylation reaction of various aliphatic amines and aniline with dimethyl carbonate was investigated

Table 4 Carbamoylation of dibutylamine with DMC in the presence of different catalysts

\begin{tabular}{llll}
\hline Catalyst & $\begin{array}{l}\text { Yield of } \\
\text { carbamate }{ }^{*}[\%]\end{array}$ & $\begin{array}{l}\text { Conversion } \\
\text { of amine [\%] }\end{array}$ & $\begin{array}{l}\text { Selectivity towards } \\
\text { carbamate [\%] }\end{array}$ \\
\hline- & Trace amounts & 11.8 & 1.1 \\
$98 \% \mathrm{Fe}_{2} \mathrm{O}_{3}$ & Trace amounts & 23.2 & 1.6 \\
$\mathrm{TZC}-3 / 1$ & Trace amounts & 6.6 & 5.8
\end{tabular}

*GC-yield versus amine.

Molar ratio of amine: DMC $=2: 1$, WHSV $=4 \mathrm{~g}$ amine $/ 1 \mathrm{~g}$ catalyst $\cdot \mathrm{h}$, reactant mixture pressure $=9.0 \mathrm{MPa}$, reaction temperature $=150^{\circ} \mathrm{C}$. The number of replicates was 3 .
Table 5 The differences between the catalytic and noncatalytic reactions

\begin{tabular}{|c|c|c|c|c|}
\hline Amine & Catalyst & $\begin{array}{l}\text { Yield of } \\
\text { carbamate*[\%] }\end{array}$ & $\begin{array}{l}\text { Amine } \\
\text { conversion [\%] }\end{array}$ & $\begin{array}{l}\text { Selectivity } \\
\text { towards } \\
\text { carbamate [\%] }\end{array}$ \\
\hline \multirow{3}{*}{$\mathrm{HA}$} & $\begin{array}{l}\text { without } \\
\text { catalyst }\end{array}$ & 52.4 & 67.2 & 78.0 \\
\hline & TZC-3/1 & 68.3 & 83.1 & 82.2 \\
\hline & $98 \% \mathrm{Fe}_{2} \mathrm{O}_{3}$ & 63.5 & 77.0 & 82.5 \\
\hline \multirow{3}{*}{$\operatorname{diBA}$} & - & Trace amounts & 11.8 & 1.1 \\
\hline & TZC-3/1 & Trace amounts & 6.6 & 5.8 \\
\hline & $98 \% \mathrm{Fe}_{2} \mathrm{O}_{3}$ & Trace amounts & 23.2 & 1.6 \\
\hline \multirow{2}{*}{ Aniline } & - & 0 & 0 & 0 \\
\hline & TZC-3/1 & Trace amounts & & \\
\hline
\end{tabular}

*GC-yield versus amine.

Molar ratio of amine: $\mathrm{DMC}=2: 1, \mathrm{WHSV}=4 \mathrm{~g}$ amine $/ 1 \mathrm{~g}$ catalyst $\cdot \mathrm{h}$, reactant mixture pressure $=9.0 \mathrm{MPa}$, reaction temperature $=150^{\circ} \mathrm{C}$. The number of replicates was 3.

and the study of the activity of five catalysts in the described process presented. The carbamoylation of linear primary aliphatic amines occurred with relatively high yields while non-linear primary aliphatic amines and secondary aliphatic amines are less active in reaction with DMC.

Aniline did not react with dimethyl carbonate in the reactions performed without a catalyst, whereby alkylation was found to take place.

The iron-chrome catalyst TZC-3/1 from Grupa Azoty Tarnów was found to be the most active catalyst in carbamoylation of $\mathrm{n}$-hexylamine. In the case of aniline, TZC-3/1 catalyst promoted the methylation processthe yield of $\mathrm{N}$-methylaniline increased from $3.5 \%$ to $10 \%$.

Two additional reactions of HA with DMC were performed in a batch reactor for comparison with literature procedures.

An illustration of the differences between non-catalytic vs catalytic results, the main yield values obtained during our experiments are presented in Table 5.

\section{Abbreviations}

DMC: dimethyl carbonate; HA: n-hexylamine; BA: n-butylamine; CHA: cyclohexylamine; secBA: sec-butylamine; diPrA: dipropylamine; diBA: dibutylamine; benzA: benzylamine; S $_{\text {BET: }}$ Brunner Emmett Teller method; BJH: Barrett-Joyner-Halenda method; GC/MS: gas chromatography and mass spectrometry.

Competing interests

The authors declare that they have no competing interests.

Authors' contributions

ML carried out the experiments and drafted the manuscript. JK supervised the entire study. Both authors read and approved the final manuscript. 


\section{Authors' information}

$\mathrm{ML}$ is a researcher in Department of Organic Technology and Separation Processes in Industrial Chemistry Research Institute. JK is a research supervisor and a Head of Department of Proecological Modernization of Technology in Industrial Chemistry Research Institute.

\section{Acknowledgements}

The authors wish to thank Grupa Azoty Tarnów and Süd Chemie for the kind gifts of the samples of catalysts for our research.

\section{Author details}

${ }^{1}$ Department of Organic Technology and Separation Processes in Industrial

Chemistry Research Institute, Rydygiera 8, 01-793 Warsaw, Poland.

${ }^{2}$ Department of Proecological Modernization of Technology in Industrial

Chemistry Research Institute, Rydygiera 8, 01-793 Warsaw, Poland.

Received: 23 July 2014 Accepted: 12 January 2015

Published online: 30 January 2015

\section{References}

1. Ullmann's Encyclopedia of Industrial Chemistry. Carbamates and Carbamoyl Chlorides, vol. A5. 5th ed. 1999. p. 51-8.

2. Adames P, Baron FA. Esters of Carbamic Acid. Chem Rev. 1965;65:567-602.

3. Green W, Wuts PGM. Protective Groups in Organic Synthesis. 3rd ed. New York: Wiley and Sons; 1999. p. 503-50.

4. Aresta M, Quaranta E. Carbon dioxide: a substitute for phosgene. Chemtech. 1997;27:32-40.

5. Twitchett HJ. Chemistry of the production of organic isocyanates. Chem Soc Rev. 1974:3:209-30.

6. Majer P, Randad R. A Safe and Efficient Method for Preparation of $\mathrm{N}_{\text {, }}$ N'-Unsymmetrically Disubstituted Ureas Utilizing Triphosgene. J Org Chem. 1994;59:1937-8

7. Norwick JS, Powell NA, Nguyen TM. An improved method for the synthesis of enantiomerically pure amino acid ester isocyanates. J Org Chem. 1992;57:7364-6.

8. Wang L, Shang J, Liu S, Liu L, Zhang S, Deng Y. Environmentally benign and effective syntheses ofN-substituted carbamates via alcoholysis of disubstituted ureas over TiO2/SiO2 catalyst. Pure Appl Chem. 2012;84:461-71.

9. Ono Y. Catalysis in the production and reactions of dimethyl carbonate, an environmentally benign building block. Appl Catal A Gen. 1997;155:133-66.

10. Kijeński J, Śmigiera E, Polaczek J. Węglany alkilowe jako zielone reagenty. Otrzymywanie i perspektywy Przemysł Chemiczny. 2004;83:493-6.

11. Delledonne D, Rivetti F, Romano U. Developments in the production and application of dimethylcarbonate. Appl Catal A Gen. 2001;221:241-51.

12. Hacking MAPJ, van Rantwijk F, Sheldon RA. Lipase catalyzed reactions of aliphatic and arylaliphatic carbonic acid esters. J Mol Catal B Enzym. 2000:9:201-8.

13. Sima T, Guo S, Shi F, Deng Y. The syntheses of carbamates from reactions of primary and secondary aliphatic amines with dimethyl carbonate in ionic liquids. Tetrahedron Lett. 2002:43:8145-7.

14. Zhou H, Shi F, Tian X, Zhang Q, Deng Y. Synthesis of carbamates from aliphatic amines and dimethyl carbonate catalyzed by acid functional ionic liquids. J Mol Catal A Chem. 2007;271:89-92.

15. Carloni S, De Vos D, Jacobs P, Maggi R, Sartori G, Sartorio R. Catalytic Activity of MCM-41-TBD in the Selective Preparation of Carbamates and Unsymmetrical Alkyl Carbonates from Diethyl Carbonate. J Catal. 2002;205:199-204

16. Vauthey I, Valot F, Gozzi C, Fache F, Lemaire M. An environmentally benign access to carbamates and ureas. Tetrahedron Lett. 2000;41:6347-50.

17. Baba T, Fuliwara M, Oosaku A, Kobayashi A, Deleon R, Ono Y. Catalytic synthesis of $\mathrm{N}$-alkyl carbamates by methoxycarbonylation of alkylamines with dimethyl carbonate using $\mathrm{Pb}\left(\mathrm{NO}_{3}\right)_{2}$. Appl Catal A Gen. 2002;227:1-6.

18. Curini M, Epifano F, Maltese F, Rosati O. Carbamate synthesis from amines and dimethyl carbonate under ytterbium triflate catalysis. Tetrahedron Lett. 2002:43:4895-7.

19. Distaso M, Quaranta E. Group 3 metal (La, Sc) triflates as catalysts for the carbomethoxylation of aliphatic amines with dimethylcarbonate under mild conditions. Tetrahedron. 2004;60:1531-9.

20. Deleon RG, Kobayashi A, Yamauchi T, Ooichi J, Baba T, Sasaki M, et al. Catalytic methoxycarbonylation of 1,6-hexanediamine with dimethyl carbonate to dimethylhexane-1,6-dicarbamate using $\mathrm{Bi}\left(\mathrm{NO}_{3}\right)_{3}$. Appl Catal A Gen. 2002:225:43-9.

21. Distaso M, Quaranta E. Highly selective carbamation of aliphatic diamines under mild conditions using $\mathrm{Sc}(\mathrm{OTf})_{3}$ as catalyst and dimethyl carbonate as a phosgene substitute. Appl Catal B Environ. 2006;66:72-80.

22. Fu Z, Ono Y. Synthesis of metyl N-phenyl carbamate by methoxycarbonylation of aniline with dimethyl carbonate using $\mathrm{Pb}$ compounds as catalysts. J Mol Catal A Chem. 1994:91:399-405.

23. Margetić D, Zrinski Antonac I, Glasovac Z, Eckert-Maksić M, Maksimović L. Reactions of dimethyl carbonate with aliphatic amines under high pressure. Synthetic Commun. 2011;41:2283-9.

24. Juarez R, Pennemann H, Garcia H. Continuous flow carbamoylation of aniline by dimethyl carbonate using a microreactor coated with a thin film of ceria supported gold nanoparticles. Catalysis Today. 2011;159:25-8.

25. Yoshida T, Sasaki M, Hitara F, Kawamani Y, Inazu K, Ishikawa A, et al. Highly selective methoxycarbonylation of aliphatic diamines with methyl phenyl carbonate to the corresponding methyl N-alkyl dicarbamates. Appl Catal A Gen. 2005;289:174-8.

26. Zhang L, Yang $Y$, Xue $Y, F u$ X, An Y, Gao G. Experimental and theoretical investigation of reaction of aniline with dimethyl carbonate catalyzed by acid-base bifunctional ionic liquids. Catalysis Today. 2010;158:279-85.

27. Dhakshinamoorthy A, Alvaro M, Garcia H. Metal organic frameworks as heterogeneous catalysts for the selective $\mathrm{N}$-methylation of aromatic primary amines with dimethyl carbonate. Appl Catal A Gen. 2010;378:19-25.

\section{Publish with ChemistryCentral and every scientist can read your work free of charge \\ "Open access provides opportunities to our colleagues in other parts of the globe, by allowing anyone to view the content free of charge." \\ W. Jeffery Hurst, The Hershey Company.}

- available free of charge to the entire scientific community

- peer reviewed and published immediately upon acceptance

- cited in PubMed and archived on PubMed Central

- yours - you keep the copyright

Submit your manuscript here:

http://www.chemistrycentral.com/manuscript/<smiles>c1ccccc1</smiles>

ChemistryCentral 